\title{
Bringing the Family Logic in: From Duality to Plurality in Social Enterprises
}

\author{
Andreana Drencheva ${ }^{1}$ (1) $\cdot$ Wee Chan $\mathrm{Au}^{2}$
}

Received: 20 August 2020 / Accepted: 7 October 2021 / Published online: 19 October 2021

(c) The Author(s) 2021

\begin{abstract}
Social enterprises combine activities, processes, structures, and meanings associated with multiple institutional logics that may pose conflicting goals, norms, values, and practices. This in-depth multi-source case study of an ecological social enterprise in Malaysia reveals how the enactment of the family logic interacts with the market and ecological logics not only in conflicting but also in synergetic ways. By drawing attention to the institutional logic of the family in social entrepreneurship, this study highlights the heterogeneity of social enterprises. The findings have implications for research with social enterprises and family-owned firms in relation to the ethical obligations of these organizations and the interactions of multiple logics.
\end{abstract}

Keywords Family-owned firm $\cdot$ Family logic $\cdot$ Hybrid organizing $\cdot$ Social entrepreneurship $\cdot$ Social enterprise

\section{Introduction}

Sky is an ecological social enterprise in Malaysia. Anyone who engages with the organization very quickly hears its members using terms such as "brother", "sister", and "family" to talk to and about each other. The norms of the family to care for each other are easily observable in everyday activities, organizational structures, budgets, and decisions. Current and former members of the organization share values, sense of belonging, and strong emotional connection whereby even those who have left the organization or were made redundant still attend events and provide support. All these indicators suggest that Sky behaves like a family-owned firm, yet there are no kinship ties within the organization.

The notion that a social enterprise that is not familyowned may exhibit characteristics common for familyowned firms suggests that the organization may enact the family institutional logic. Institutional logics are broadly

Andreana Drencheva

a.drencheva@sheffield.ac.uk

Wee Chan $\mathrm{Au}$

au.wee.chan@monash.edu

1 Sheffield University Management School, University of Sheffield, Sheffield, UK

2 Department of Management, Monash University Malaysia, Subang Jaya, Malaysia defined as the shared meaning systems that guide individual and organizational behavior in relation to which goals, norms, values, and practices are desirable and acceptable in a field (Thornton et al., 2012). Social enterprises are usually described as combining the conflicting social welfare (or ecological; York et al., 2016) logic to pursue social/ecological change, common for non-profit organizations, with the market logic that prioritizes efficiency and profits, typical for commercial organizations (e.g., Pache \& Santos, 2013). However, the family logic that embraces goals, norms, values, and practices related to family cohesion, continuity, and support (Jaskiewicz et al., 2016), common in family-owned firms, so far has not been empirically explored in social enterprises, despite the conceptual comparisons between social enterprises and family-owned firms (Bacq \& Lumpkin, 2014; Börje \& Nordqvist, 2020; Whetten et al., 2014).

In this article, we examine the following research question with an inductive, in-depth, multi-source case study analysis of Sky: How does the enactment of the family logic in an ecological social enterprise interact with the existing market and ecological logics? Based on our analysis, we explicate how the family logic emerged in Sky in response to the challenges of combining the ecological and market logics. While the family logic interacted with the other two logics in synergetic ways by creating resources to meet the demands associated with the market and ecological logics, it also conflicted with the other two logics by introducing new contradictory demands. By examining the family logic 
within an ecological social enterprise that already combines ecological and market logics, we move beyond the dominant empirical focus on two conflicting logics. This dominant approach may neglect less visible logics, types of interactions between logics, and stakeholders, thus offering a limited reflection of how social enterprises function and concealing their heterogeneity.

Our findings have three core implications for research in social entrepreneurship and family-owned firms. First, we expose the enactment of the family logic in a non-family-owned social enterprise, thus contributing to a better understanding of the heterogeneity of social enterprises. By surfacing the family logic, behaviors and decisions that seem illogical or undesirable within social enterprises can be better understood, while also emphasizing the experiences of internal stakeholders, such as employees, beyond the dominant focus on external stakeholders, such as beneficiaries. Second, our findings provide initial insights into the interactions between ecological, market, and family logics in social enterprises in fluid and dynamic ways embedding synergies and contradictions. Thus, we contribute to the emerging stream of research on the plurality of institutional logics (e.g., Gottlieb et al., 2020; Jay, 2013; Savarese et al., 2020), beyond duality, and call for authentic representation of social enterprises that captures the logics present in them, instead of assuming only two conflicting logics. Finally, our findings shed light on the relationships between ethics and institutional logics and provide nuance to our understanding of the ethical challenges for social enterprises and family-owned firms from an ethics of care perspective (Tronto, 1993). The emergent insights raise questions about the ethical responsibilities of organizations not only toward beneficiaries concerning benefit, mission drift, voice, and governance (Bull \& Ridley-Duff, 2019; Ramus \& Vaccaro, 2017), but also toward (potential) employees in how ethics of care are enacted toward those inside and outside of the organization.

\section{Theoretical Background}

\section{Social Enterprises and Institutional Logics}

Social enterprises address social issues, such as poverty, homelessness, ecological degradation, or inequality, with market-based mechanisms (Mair et al., 2012). Care and compassion are central in social venturing (André \& Pache, 2016; Miller et al., 2011; Stephan \& Drencheva, 2017) and thus align with the principles of ethics of care (Tronto, 1993). Social enterprises are considered organizations that care about specific social issues or people and take on the responsibility to care for them and to give care through encouraging caring relationships among members of the organization (André \& Pache, 2016; Magrizos \& Roumpi, 2020). Thus, social enterprises embed elements common for non-profit and commercial organizations. Accordingly, social enterprises can be conceptualized as hybrid organizations that combine heterogeneous institutional logics from different fields (Doherty et al., 2014; Laasch, 2018).

Institutional logics are defined as taken-for-granted beliefs and practices that guide actors' behavior in fields of activity (Friedland \& Alford, 1991; Thornton et al., 2012). Broadly, institutional logics associated with the capitalist market, bureaucratic state, community, nuclear family, religion, and profession are recognized (Friedland \& Alford, 1991; Thornton et al., 2012). The principles carried by various institutional logics cover multiple aspects of what is desirable and acceptable for organizations: the nature of ownership, the mode of governance, business models, activities, operational priorities, stakeholder engagement (e.g., Jay, 2013; Vaskelainen \& Münzel, 2018; York et al., 2016), thus enabling endorsements and access to resources (DiMaggio \& Powell, 1983; Greenwood et al., 2011). For example, the market logic prioritizes economic efficiency and profits that can be legitimately appropriated by the owners of commercial organizations, the ecological logic prioritizes activities and solutions that address ecological degradation in sustainable ways (York et al., 2016), and the family logic embraces the family unit as an institution with norms, values, and goals related to cohesion and continuity (Jaskiewicz et al., 2016).

\section{Heterogeneous Institutional Logics in Social Enterprises}

Hybrid organizations embed heterogeneous logics combining market and non-market logics, such as state, religion, and family (Laasch, 2018), that often interact in conflicting and contradictory ways. For example, family-owned firms combine the market and family logics (e.g., Börje \& Nordqvist, 2020), social enterprises combine the market and social welfare logics (e.g., Pache \& Santos, 2013), and sustainability businesses combine the market and ecological logics (e.g., York et al., 2016). The combination of multiple institutional logics poses challenges because institutional logics are often in conflict with each other: each institutional logic prescribes different demands and thus satisfying the demands of one logic may result in defying the demands of another logic. In the context of social enterprises, conflicting demands imposed by different institutional logics can jeopardize an organization's legitimacy with external stakeholders who may see the organization as, for example, too social or too commercial and not social nor commercial enough (Galaskiewicz \& Barringer, 2012). Such legitimacy issues matter for social enterprises because legitimacy, as perceptions of appropriateness and alignment with socially constructed 
norms, values, and definitions, enables access to resources (Suchman, 1995). Internally, social enterprises may face contradictory practices and behaviors (Tracey et al., 2011) and conflict between groups (Battilana \& Dorado, 2010), thus jeopardizing the operations of the organization and potentially leading to crisis (Battilana \& Dorado, 2010), closure (Tracey et al., 2011) or mission drift (Ramus \& Vaccaro, 2017), consequently betraying the organization's ethical obligations toward stakeholders.

While research on social enterprises as hybrid organizations has enhanced the understanding of how social enterprises address social issues, engage with stakeholders, avoid and rectify mission drift (Battilana \& Dorado, 2010; Battilana et al., 2015; Pache \& Santos, 2013; Ramus \& Vaccaro, 2017; York et al., 2016), two significant issues remain.

First, research with social enterprises has predominantly focused on the conflicting demands between the social welfare (e.g., Pache \& Santos, 2013) (or ecological, York et al., 2016) and market logics. However, organizations face institutional complexity reflecting the experience of incompatible prescriptions from multiple logics, or institutional pluralism, reflecting the co-existence of multiple, but not necessarily incompatible, prescriptions (Ocasio \& Radoynovska, 2016). For example, institutional logics may reinforce each other or temper each other (e.g., Greenwood et al., 2010). Additionally, the co-existence of multiple institutional logics can create benefits, such as providing new combinations of knowledge, resources, and practices and exposing taken-for-granted assumptions that catalyze innovation and strategic change (Ocasio \& Radoynovska, 2016; Reay \& Hinings, 2009). This also means that hybrid organizations have opportunities for strategic choices leading to differences in value creation and in value capture as well as opportunities to engage with a wider set of stakeholders and referents (Greenwood et al., 2011). Overall, the co-existence of multiple institutional logics is essential for hybrid organizations to achieve their mission through novel combinations. For example, to address social issues in financially and operationally sustainable ways in the case of social enterprises (Battilana et al., 2015) or to fulfill family interests while sustaining a commercial organization in the case of family-owned firms (Jaskiewicz et al., 2016). Yet, these types of 'positive' interactions between logics, and consequently the effects of these interactions for organizations, are rarely considered in the social entrepreneurship literature. The dominant focus on the social welfare and market logics also prioritizes external stakeholders, such as beneficiaries and customers, while internal stakeholder, such as employees, and their experiences are neglected.

Second, social enterprises are typically studied from a duality perspective - how elements of two logics interact with specific outcomes for the strategy of social enterprises (e.g., Muñoz et al., 2018; York et al., 2016). However, social entrepreneurship research has neglected the potential for more than two logics to be embedded in a social enterprise, despite calls for investigating a broader range of institutional logics beyond the dominant market and social welfare logics (Greenwood et al., 2011; Jaskiewicz et al., 2016). Indeed, emerging research on strategic public-private partnerships as a form of hybrid organizing demonstrates that the market, state, community, and specific professional logics can interact simultaneously (Gottlieb et al., 2020; Jay, 2013), while research with family-owned firms suggests that the family, market, religion, state, and community logics can interact (Fathallah et al., 2020; Greenwood et al., 2010). Yet, such interactions between multiple, not just dual, logics are not empirically investigated in the context of social enterprises and the family logic has been neglected in the social entrepreneurship domain. In this study, our core research question is how the enactment of the family logic in an ecological social enterprise interacts with the existing, within the organization, market and ecological logics.

\section{Characteristics of the Family Logic}

The logic of the family is most clearly visible in familyowned firms where members of a family exert significant influence through controlling ownership and/or management (Bingham et al., 2011; Boers \& Nordqvist, 2012; Börje \& Nordqvist, 2020). Aligned with a logic that prioritizes the family, family-owned firms are characterized by the non-economic benefits that result from kinship ties in organizations (Cruz et al., 2012; Schulze et al., 2003) and by a responsibility toward the family, including future generations (Brundin et al., 2014; Chrisman et al., 2003). Core to family-owned firms is the notion of familiness, which is defined as "the idiosyncratic firm level bundle of resources a particular firm has because of the system interactions between the family, its individual members, and the business" (Habbershon et al., 2003, p. 451).

Indeed, family-owned firms are highly particularized in their values and norms. The values idiosyncratic to the family permeate the organization and shape a distinct organizational culture (Dyer, 2003; Habbershon \& Pistrui, 2002) with caring behaviors and commitment (Gomez-Mejia et al., 2011; Schulze et al., 2001), cultivating shared goals and norms among employees (Cruz et al., 2012; Gomez-Mejia et al., 2007, 2011; Rowley et al., 2000). Such unspoken norms and traditions are influential in firm decision making and contribute to high levels of participation among members of the organization (Sorenson, 2000), affective attachment to the firm and identification with the firm (GomezMejia et al., 2011), even among non-family members of the organization. The strong identification with the organization, even among non-kin members, also means that members are likely to engage in organizational citizenship behaviors 
(OCBs) (Miller \& Le Breton-Miller, 2005). OCBs are extrarole behaviors that benefit others, such as offering help to a co-worker or adhering to norms that are unwritten and outside of formal job descriptions (Organ, 1997), yet essential for organizational functioning. Additionally, intimate and communal relationships, informal arrangements, and high levels of trust, commitment and loyalty among members (Bingham et al., 2011; Brundin et al., 2014; Chrisman et al., 2005; Hoffman et al., 2016) are common in family-owned firms as an expression of the family logic which emphasizes continuity, unity, and cohesion (Jaskiewicz et al., 2016). This is also expressed in a commitment to the continuity and longevity of the firm (Brundin et al., 2014), thus maintaining family values and norms. Such expressions of the family logic through relational concerns, cohesion, caring norms and practices also aligns with the principles of ethics of care (Gilligan, 1982; Tronto, 1993), which have been considered in the context of family firms (Long \& Mathews, 2011).

The family logic in family-owned firms can contribute to competitive advantages; however, its expression can also present challenges and ethical issues. Consistent with the logic's prioritization of the family, family-owned firms tend to focus on the wellbeing of their internal constituents, including hiring, promoting, and rewarding less capable family members (Bingham et al., 2011; Chrisman et al., 2014Chua et al., 2009). At the same time, as the focus is on the unity and continuity of the family and the firm as an extension of the family, members in familyowned firms arguably tolerate working conditions that do not meet their needs (Bacq \& Lumpkin, 2014). The strong affective attachment among members can impede innovation due to normative pressure, groupthink, and a lack of new sources of information from the external environment (Arregle et al., 2007). The family logic offers explanations for family-owned firms' low risk taking, tolerance of lower financial returns, and avoidance of workforce reduction (Dyer \& Whetten, 2006; Greenwood et al., 2010; Kalm \& Gomez-Mejia, 2016). Overall, past studies show that firm behavior in accordance with the family logic tends to impair the pursuit of commercial goals (Gomez-Mejia et al., 2011; Greenwood et al., 2010; Lubatkin et al., 2005; Miller et al., 2011; Schulze et al., 2001, 2003). Thus, business decisions that seem to be financially inexplicable and unprofessional to outsiders might be logical from the perspective of providing non-financial benefits to internal stakeholders in familyowned firms (Kalm \& Gomez-Mejia, 2016).

While family-owned firms and social enterprises have been conceptually compared (Bacq \& Lumpkin, 2014; Börje $\&$ Nordqvist, 2020; Whetten et al., 2014) due to common characteristics, such as pursuit of non-financial goals and care for multiple stakeholders, there is no empirical investigation of the family logic in social enterprises. Yet, it is possible for the family logic to be present in some social enterprises. Exploring the enactment of family logic and its interactions with other logics within a social enterprise is important for three reasons. First, social enterprises typically operate in organizational fields characterized by a plurality of logics (Besharov \& Smith, 2014; Mair et al., 2015). However, how social enterprises embed more than two logics is rarely investigated (c.f., Savarese et al., 2020). Second, investigating multiple logics within a social enterprise opens opportunities to understand how institutional logics interact beyond conflict. Third, specific logics are associated with specific stakeholders who grant legitimacy to organizations based on their different expectations (Fisher et al., 2017). Thus, a focus on only two logics may exclude relevant stakeholders and differences between internal (e.g., employees) and external stakeholders (e.g., beneficiaries). By considering the potential of other logics, in addition to ecological and market, to be embedded in a social enterprise, we uncovered the presence of the family logic in a social enterprise that did not have any kinship ties. By doing so, we offer a more holistic and comprehensive understanding of how social enterprises function, and provide an explanation for an interesting phenomenon that otherwise seems illogical.

\section{Methods}

This study did not begin as an exploration of how the enactment of the family logic interacted with other logics within a social enterprise. Rather, it grew out an inquiry into the internal organizing activities of a social enterprise and how competing ecological and market demands were enacted within the organization. Our case is Sky, a pseudonym to protect the identity of the participants. Sky, formed in 2012, is a social enterprise based in Malaysia with an ecological mission. Sky develops products, services, and initiatives that enable individuals, organizations, and industries to re-think and re-imagine their consumption and production toward a more sustainable future. Sky is an organization that has Social Enterprise Accredited Plus status (SE.A Plus). Social Enterprise Accreditation is the only mechanism in Malaysia to certify the status of an organization as a legitimate social enterprise whereby the Plus level is reached by a limited number of organizations whose status is recognized by the Ministry of Finance and the Inland Revenue Board of Malaysia (MaGIC, 2019).

Very soon after starting fieldwork, we were struck by the values, affective attachment, language, and norms usually associated with families. We considered this unusual because the social enterprise we engaged with was not a family-owned firm. Thus, we refocused on this interesting phenomenon (Davis, 1971) that was transparently observable (Eisenhardt, 1989). Meanwhile, an inductive research design with a single case is appropriate for 'how' research 
questions (Edmondson \& McManus, 2007; Yin, 2003) and in complex entrepreneurship settings (Henry \& Foss, 2015), such as ours, because it allows for a sharp focus on a specific phenomenon that may be less visible across organizations with different social missions, structures, and business models (Langley \& Abdallah, 2011).

\section{Data Collection}

We conducted fieldwork between August 2019 and January 2020. Our data sources include (1) formal interviews, (2) observations and notes from dozens of informal interviews with internal members and stakeholders of Sky captured in a comprehensive field diary, and (3) archival information (see Table 1).

\section{Formal Interviews}

We conducted formal semi-structured interviews, which enabled us to capture rich and detailed accounts of individuals' personal experiences within and with Sky. In addition to nine current members with different tenure (two founders, two partners as senior leaders, three employees, and two interns) across different units of Sky, capturing 64\% of the full-time team, we also interviewed one founder and one employee who had left Sky but were still informally engaged. We started interviews with structured questions to capture the participants' personal motivations, histories, and experiences. As each interview progressed, we asked

Table 1 Data sources

\begin{tabular}{ll}
\hline Source & Number of sources \\
\hline Interviews (formal and informal) & 9 \\
With founders & 7 \\
With partners & 14 \\
With current employees & 4 \\
With former employees & 3 \\
With members of social enterprise support and \\
membership organizations & 14 \\
With clients and collaborators & \\
Observations & 6 \\
Team meetings & 2 \\
Townhall meetings & 3 \\
Social events & 7 days \\
Business delivery & 22 days \\
Observation in office & \\
Archival records & 8 \\
Sales presentations and proposals & 6 \\
Internal governance documents & 12 \\
Project updates & 12 \\
Media &
\end{tabular}

questions about the organization's challenges, typical behaviors, relationships, and norms, as well as individuals' conceptualization of family inside and outside of Sky. Additionally, we interviewed an ecosystem builder from a support organization who had closely worked with the founding team since its early days and had become a confidant and a mentor. His sharing helped us to triangulate certain experiences and provided additional insights. Interviews took between 45 and $80 \mathrm{~min}$, averaging $64 \mathrm{~min}$. All interviews were recorded and transcribed.

\section{Field Observations}

We observed project and team meetings, monthly townhall meetings with all members, and social events for current and former members and collaborators. Additionally, we observed core business delivery, such as programs, services, and product manufacturing. During breaks and at the end of events or meetings, we asked questions for clarification and checked inferences. The details of observations, including content, processes, key incidents, interactions, and quotes, were recorded in notebooks as they happened (cf., Zilber, 2002) and typed up usually at the end of each day. We also conducted dozens of informal conversations with current and former members of Sky and stakeholders, such as clients, beneficiaries, and collaborators. This included an informal interview with a senior member of a social enterprise membership organization who had closely worked with one of the founders and had become a mentor/confidant. During fieldwork, we conducted additional informal interviews with participants who had already been formally interviewed to check inferences, clarify insights, and collect additional data. Notes from all informal conversations were recorded in the field notebooks. Overall, observations allowed us to triangulate insights and capture how the family logic was enacted through daily actions and interactions, such as specific vocabulary used between members to talk to each other, offers for help, gestures that were not common in traditional commercial organizations.

\section{Archival Information}

Finally, we were provided with internal documents, such as annual reports, strategic governance documents, and business plans, and accessed publications in the media about the organization. These documents provided important background information about the organization and its context. More importantly, internal documents allowed us to triangulate insights gained from interviews in relation to how the ecological and market logics interacted and how the organization approached emerging tensions through formal mechanisms, such as pricing of products, development of new products, etc. 
All data was stored and managed using NVivo 12 with anonymized copies.

\section{Data Analysis}

We followed common prescriptions for inductive qualitative data analysis (Corley \& Gioia, 2004; Gioia et al., 2013; Zietsma \& Lawrence, 2010). We started iterative data analysis in parallel to data collection to identify how the family logic was enacted within the organization. While we describe this process as linear for clarity, the process was iterative, moving between and among the data, relevant literatures on institutional logics, family-owned businesses, and emerging patterns to refine the analysis (Gioia et al., 2013).

Our first analytical step was to categorize the raw data into first-order categories that made participants' point of view the foundation of the analysis (Gioia et al., 2013). We coded units of meaning with "in-vivo" labels using the participants' language, where possible, or simple phrases to describe the meaning of the unit. We applied the constant comparison technique by comparing each unit of meaning to the previous one in the data source as well as all units within a category to one another. This technique allowed us to ensure that all units of meaning within a category reflected the same experience, thus clarifying categorical boundaries.

As first-order coding continued, we started to reflect on the relationships between first-order codes to develop second-order themes (Gioia et al., 2013). The first-order categories described the participants' experiences in their own words but lacked theoretical meaning. This is why we abstracted and consolidated first-order categories into second-order themes and dimensions based on their relationships. These second-order themes and dimensions represented theoretical interpretations of the participants' lived experiences (Gioia et al., 2013). We applied the constant comparison technique again, this time at the level of themes to ensure they were clearly differentiated, yet captured the nuanced meanings of the first-order categories within them. When we created, merged, or changed themes, we reanalyzed all previously analyzed data based on the new set of themes. This meant that while our first-order categories represented the participants' experiences in their language, our second-order themes were more theoretically nuanced.

When we were confident in the robustness of the boundaries between second-order themes, we consolidated them into overarching theoretical dimensions. This involved looking at the relationships between the second-order themes and abstracting them into more parsimonious categories with theoretical meaning. At this stage, we engaged with the literature to identify appropriate theoretical lenses that could explain our emergent empirical insights related to the notion of the family. The notion of the family logic from the institutional logics literature (e.g., Friedland \& Alford,
1991; Thornton et al., 2012) provided the scaffolding for how we conceptualized the phenomenon in terms of takenfor-granted values and norms that guide behavior. Whereas the literature on family-owned businesses (e.g., Cruz et al., 2012; Gomez-Mejia et al., 2001, 2007, 2011; Jaskiewicz et al., 2016) helped us to define these values (i.e., shared ecological values, belonging, affective attachment with a family vocabulary) and particularized norms (i.e., care for others) with their potential influence on how the family logic interacted with the market and ecological logics through two different mechanisms: generating new resources for shared demands and introducing new conflicting demands. At this stage, we also contrasted the family logic to the ecological and market logics (see Table 2) to ensure that indeed what we had identified represented a distinct logic instead of a variation or a combination between the market and ecological logics. We established three overarching dimensions with nuanced relationships between each other: (1) challenges associated with the interaction between ecological and market logics that served as a foundation for (2) the emergent family logic, which (3) interacted with the market and ecological logics in synergetic and conflicting ways.

We took several steps toward establishing the trustworthiness of the findings (Lincoln \& Guba, 1985). First, during data collection, we performed a number of checks to clarify details, accounts, and inferences. Second, we used multiple data sources to triangulate data. Third, the foundation of our analysis is the accounts and language of the participants, while differentiating between first- and second-order categories, themes, and dimensions enabled us to develop theoretical rigor and parsimony. The relationships between first-order categories, second-order themes, and aggregated dimensions are presented in a progressive data structure (Gioia et al., 2013) (see Fig. 1).

\section{Findings}

\section{Challenges Associated with the Interaction Between the Ecological and Market Logics: Foundation for Emergent Family Logic}

As a social enterprise, Sky combined the ecological and market logics, which introduced competing demands. Sky was deeply committed to making a positive ecological impact through reducing use of resources, reusing resources, developing new ways of working that were more sustainable, and measuring their ecological impact, for example, based on the amount of waste saved from landfills (from archival documents). Yet, it also required economic profitability and efficiency in its trading and operations to maintain its existence. 
Unsurprisingly, as demonstrated in the social entrepreneurship literature (e.g., Galaskiewicz \& Barringer, 2012), the organization lacked legitimacy as a social enterprise. Additionally, it also lacked legitimacy as an organization embedding ecological practices. For example, "this kind of business was very new to them [stakeholders], talking about the environment, talking about social impact" (Partner \#1), "No one, no one even knew what social enterprise was." (Founder \#2). This lack of awareness of social entrepreneurship continuously presented "the whole bigger reality that everyone thinks that we are charity" (Former Employee) and limited commercial opportunities: "they [corporate clients] don't really give you the time of day, so that part is hard...in getting their recognition...or getting contracts from them." (Founder \#2). The organization also faced "the fact that people weren't so aware of sustainability practices, I mean, of course, people did undertake sustainability practices, but it was not very widely spoken about, and it wasn't really the direction of companies" (Partner \#1), including lack of understanding of specific sustainability practices: "they still understand it in a way where Sky is doing recycling, which is completely not what we are doing. We do upcycling." (Founder \#2). Such a lack of legitimacy made it difficult for Sky to compete with commercial organizations while achieving its ecological goals. As Founder \#1 shared:

You need to be competitive in your prices, you need to be um, what's the word? Cut-throat in your negotiations with your clients. When people are engaging us to do education programs for the long term, we have to be quite competitive. We cannot say 'Look, we come with impact reports, so you have to pay us more.' They are like, 'I don't care, get the bloody work done, and the impact report, find your own time to do it.'

In this context, "we don't have enough money to sustain ourselves, so every job counts" (Partner \#2). Financial challenges were common and "looking so scary that we really don't know if we are going to survive" (Founder \#3). Such financial insecurities and challenges resulted in resource constraints and limited talent within the organization to deliver the work required: "there are instances where the development could have taken a much shorter time, but with the resource we have, the timeline is what it is" (Partner \#1); "But how do we make more content? We are already struggling with producing the images and videos as it is. Who is going to do it?" (Partner \#2 to Founder \#1; field notes). Yet, the organization often could not afford to hire new talent or the best talent:

I need another hire, hopefully I can clone myself, that'll be great, but that is not possible yet (laughs) [...] probably soon [the hire], but not yet, when we get our steady flow of jobs (Partner \#2) 
First-order categories

- Ecological mission at the core of the social enterprise

- Lack of awareness of ecological practices and values

- Lack of understanding of social entrepreneurship

- Need to be financially efficient

- Challenges in gaining customers

- Challenges in recruiting talent

- High ecological goals and drive for positive ecological impact

- Costs associated with ecological goals

- Commercial goals

- Recruit and retain talent based on ecological values

- Members express passion for sustainability

- Members continuously learn about sustainability

- "I am my authentic self here", even when I leave

- Not alone

- Commitment and loyalty to the organization and members

- Use of family vocabulary to refer to members of the social enterprise

- Expression of strong psychological connection

- Trust amongst members

- Offer emotional support to other members

- Offer tangible support to other members

- Embed care for others in organizational practices and budgets

- Rely on other members for support

- Employee commitment

- Take on extra-role activities and projects

- Delayed and prolonged downsizing

- Issues with professionalism

- Acceptance of greenwashing projects

Fig. 1 Data structure

if we compare to the market, no I don't think we're being paid fairly, as a result of that we do struggle to employ the best talent (Founder \#1)

\section{Emergent Family Logic: Synergies with Other Logics Based on Generating New Resources}

In response to the challenges of combining the market and ecological logics, binding affective family ties without kinship were developed in Sky that could be best described as an emergent family logic that embraced taken-for-granted family values, practices, norms, and goals prescribing acceptable and desired decisions and behaviors. In these circumstances, the family logic served as an asset that helped address the trade-offs between the ecological and market logics. The family logic interacted in synergetic ways with the other two logics. It enabled achievement of market and ecological goals because it generated new resources-committed talent who worked long hours to deliver projects and
Second-order themes

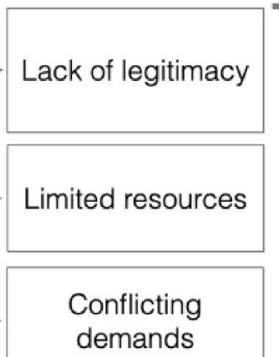

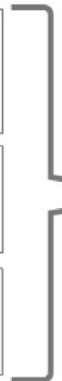

Aggregated dimensions

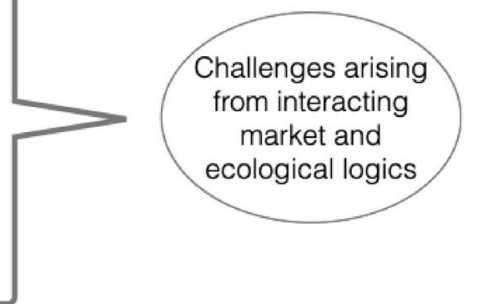

Shared ecological values

Belonging

Affective attachment others

Synergetic resource generation

New conflicting demands

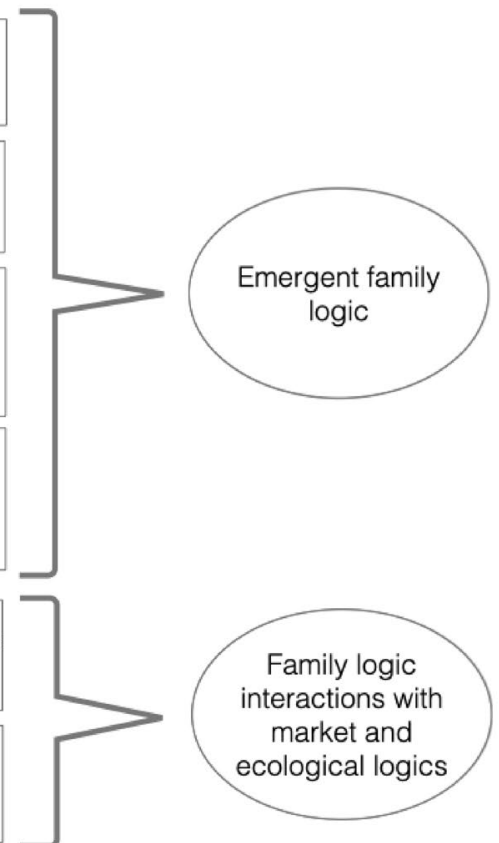

to provide support to others that were essential for the team to deal with the trade-offs between the ecological and market logics.

The first defining characteristics of the family logic in Sky were the shared ecological values that created a sense of belonging and a commitment to the longevity of the organization, thus overlapping with the ecological logic. Sky was founded with strong ecological values at a time when there was limited awareness of sustainability in Malaysia. These values were core to the founders' decision to start Sky: "we wanted to do things our way. We had a different vision, different values, and that's when we decided to take the leave to start our own enterprise" (Founder \#3). The commitment to these ecological values attracted individuals who shared them, who felt a sense of belonging and fit, while also lacking opportunities for an authentic expression of these values in mainstream society. For members, Sky represented their "home" where they felt accepted and safe to express their authentic selves: 
I want to leave a mark on how to make changes in the fashion world. So, I feel like... coming here is actually a great place for that. (Employee \#3)

Emotionally you feel free because you feel people are supportive, people are okay to express this, express that, and people accept [you], there is little judgement [...] I actually feel my own authentic self here. (Intern \#2)

These strong ecological values resulted in a unique culture recognized internally and externally that was strengthened and maintained through selection and socialization. By recruiting individuals who shared a commitment to sustainability, Sky created "this kind of community feeling, this family feeling" (Founder \#3) "that binds us together" (Former Employee). Not only was this culture of shared ecological values and belonging cherished by the members of Sky, but it was also recognized by external stakeholders: "their culture is somewhat I think unorthodox, it stands out" (Ecosystem Builder \#1). These shared ecological values were further strengthened through socialization because almost everyone who worked in Sky was a founder or started as an intern, including the partners. Indeed, Sky rarely hired for permanent roles externally and only advertised posts openly when they could not be filled internally. For example, Employee \#1 reflected: "before this I was the sustainability intern, turned sustainability executive, and currently I am doing the business development and sales role", while Founder \#2 shared: "some of our interns stay on for a very long time, as in they get hired after their internship, and our first ever hire was an intern, and now she's one of the partners".

Members' sense of belonging continued even after their exit from the organization. During our observations, we noted multiple former members returning to Sky for social catch-ups, events, and to provide support months and years after their exit. Such returns to the organization were common for individuals across all levels and tenures, from interns to founders. For example, Founder \#3 had officially left their role as a full-time member of the organization but continued to join for events and social activities because "having such a community, such a family around me, people who believe in the same thing" maintained their sense of belonging. The Former Employee shared their return after time abroad:

That is also why, when I felt lost and depressed, when I first came back from overseas, I was bringing a big backpack, I went back to the [Sky] office, I was hugging everyone. I felt finally I was home. [...] When I came back, everyone was telling me "Welcome to the family again."

The next defining characteristic of the family logic in Sky was a strong affective attachment between members expressed with a family vocabulary and high levels of trust. All members expressed strong psychological connections with each other and attributed strong emotional significance to their membership in the team. Words such as "family", "(big) brother", "(big) sister", "sibling” were used by everyone in the organization in a routine manner to refer to members and to describe their relationships with and between founders, partners, and (former) colleagues. For example, "[It] is like family members but even closer because we share the same [ecological] philosophy" (Former Employee); "found my own family here" (Founder \#3); "as a family, I feel..." (Employee \#2). Everyone acknowledged that "people get really attached" (Intern \#1) and "that attachment was really strong" (Former Employee) whereby individuals identified with the team because "if they are okay then I am okay" (Former Employee) and "my work is my family" (Employee \#1). Even when members left, "they are still a part of the family." (Founder \#2). The strong affective attachment between the members of Sky was recognized both internally and externally. For example, Founder \#2 shared how the team had been compared to a cult before: "We have been called that [a cult] before. We are just a family" (field notes).

This affective attachment also shaped high levels of trust. The phrase "We've got each other's back always." was continuously repeated by all organizational members in formal and informal interviews and enacted in daily activities. As Partner \#2 reflected: "trust is the main thing in our working environment, even among your team members, even among the interns". Overall, the members of Sky created strong binding ties between each other and depended psychologically on each other for support and gratification:

He [Founder \#1] is more like a big brother, and our relationship is more friendly. I don't put a lot of pressure on him. I try to take some of his pressure. And then when I have pressure, I talk to him, and then we figure it out. It's more of a brotherly thing. Our relationship is not like a boss to employee. It's more brotherly (Employee \#2)

The final defining characteristic of the family logic in Sky was the norm of caring for members based on the strong affective attachment and sense of belonging. This included intangible support whereby all members of Sky provided emotional support to each other and relied on such support for matters at work and outside of work:

I am here. There is [a] person who care[s] about you. You can always come to me. I am the finance person, [and] I am the HR person, there is professional with me. You can always come to me for one-to-one talk 
if anything happens, even outside of work, inside of work. I'm not being paid to do that. (Former Employee)

You're working with a family member, you know that we will care for you when you get sick or when you are too stressed out or you burn out (Employee \#1)

The norm of care for members also included tangible support with projects and initiatives beyond formally allocated roles and teams: "if the issue is not related specifically to an area of mine, I try to help them with resources, or networks, or whatever they need, to solve that issue" (Partner \#1). The norm of care for others was very strong and extended to individuals who were no longer a part of the team, but still proactively provided tangible and intangible support: "I am still involved, there are still...my... best friends, my family here, so...I am still involved as an adviser. I still speak to them about key issues. I still assist" (Founder \#3). This norm of care for others was embedded in routines and practices, such as during monthly townhall meetings and weekly team meetings whereby members were encouraged to share what they needed help with:

[It] is every Monday, and is all interns, and all supervisors, everyone working in [Team A]. We huddle together, we share what we are working on, what project we are going to work on, what ideas we have. They share how they can help, they share what help they need, and they share their concern (Intern \#2)

This was also evident in the townhall meetings when individuals shared what they and their teams needed: "Partner \#3 reminds everyone again of the need for seamstresses and manual laborers for Team B" (field notes).

The shared ecological values, sense of belonging, affective attachment, and norms of care that characterized the enactment of the family logic generated resources within Sky to successfully deliver ecological projects and operate efficiently, as prescribed by the market logic, even with limited human and financial resources. Members of Sky worked long hours because of their continuous effort to care for others and proactively offer emotional support, resources, and time. All members of Sky accepted and normalized working long hours, including on weekends, not questioning the overload: "even Sundays, I also come in to work, and it's no issue" (Partner \#2); "Even a communications intern in [Team B] ends up moving boxes of fabric around because that is what we all do. I do it. Founder \#1 does it." (Employee \#2); "oh this person, look at him, he's doing so much...so I will do as much as he is doing too" (Intern \#1). However, the emergent family logic also introduced new contradictory demands that conflicted with the market and ecological logics, which we explain next.

\section{Emergent Family Logic: Conflict with Other Logics Based on Introducing New Conflicting Demands}

While the family logic interacted with the ecological and market logics in synergetic ways by generating resources, it also existed in conflict with the other two logics because it introduced new competing demands. In providing care for others in the organization through emotional and instrumental support beyond allocated roles, the family logic conflicted with the ecological and market logics in jeopardizing the delivery of ecological projects and financial outcomes. All members of Sky experienced issues with and made references to exhaustion and burnout due to the competing demands between their allocated roles and the norm to care for others, which required not only time but also cognitive resources. For example, Employee \#1 reflected on the fact that the organization had sent out only one newsletter in nine months after they offered to help with the newsletter: "I am the person who does comm[unication]s for Teams A and C now on top of all the other things like sales and developing new partnerships and projects" (field notes). Echoing a similar sentiment of exhaustion, the Former Employee reflected on the challenges between supporting others, performing their financial role, and looking after themselves:

Honestly, I was quite exhausted through[out] the whole process [...] I want to take care of everyone before I take care of myself first. [...] But at the same time, you know, you are keeping everything in check, so you are doing your job. But that's quite exhausting because you don't want to do it as a friend, but as the role you are being hired, you have to do it.

Exhaustion from providing care in the form of emotional and instrumental support raised questions about individuals' effectiveness in their allocated roles as aligned with the market and ecological logics. Importantly, providing labor for projects without the required expertise, as a form of care, also meant that sometimes products and services did not meet the professional standards expected by clients and aligned with the market logic:

They didn't bill it in time, or they delivered something that doesn't look nice, then I have to deal with the client, and then the client is angry. (Partner \#2)

The norm of care for others was embedded in organizational practices and structures. However, it was not constrained only to support in the workplace or only about workrelated issues. All members of Sky supported each other with personal matters, such as career development, financial issues, family matters. Such support prioritized members' needs, sometimes in contradiction to the commercial needs of the organization, exemplifying a tension between the family and market logics. For example, individuals' careers were 
prioritized even when that meant potentially losing team members, despite the challenges of recruiting talent mentioned earlier:

Sometimes they do say, "I'm thinking about my future. I do want to stay in Sky, but I don't know whether there's anything else out there for me". I would encourage them to go out and say, "Sky will always be here". I know that they have this passion or this connection with Sky, but what they learn outside would be so much more than what we can offer (Founder \#2)

The norm of care for others also included providing financial support in multiple forms that were embedded not only in the culture of the organization but also in organizational structures and budgets. For example, to support team members and their families, Sky set up an emergency fund that members could use for personal or family matters and developed a routine to share income-generating opportunities with the families of team members:

Whenever we have a catering order or have any opportunities, we ask the team, "Hey, look, we need a catering order for 500 curry puffs. Any of your mothers or any of your dads could help?" So we try to push back some of the opportunities within the organization back when... For example, sometimes we needed extra people to come work on the weekends, we open it to our team members' parents who are not working, "Do you want to come?". So whenever there is an opportunity within the company, we open it up first if anyone needs it (Founder \#1)

However, such income-generating opportunities for team members' families did not always result in products and services meeting market standards:

It's a fine line between [being] inclusive and also professionalism [...]we had production deadlines challenges, so then after that, we're like, "Hey, look, it's quite hard." and then it makes it hard to keep people accountable because you're too closely related to the source of the problem. (Founder \#1)

The strong emotional connection between members and the norm of care for others also posed financial pressure for Sky, challenging its financial sustainability and ecological mission. Following a long and difficult period of financial struggles, Sky decided to downsize to survive and maintain its ecological mission. However, these financial challenges were at least partially related to the norm within Sky to care for others, as reflected by the Former Employee:

And in the financial role, I always advise. We need to make the shuffle. We cannot keep hiring people because we are friends, we have to be less emotional about signing long-term contracts with all our employees. So, before I left, as a financial person, I kept proposing that. In order for long-term sustainability for everyone, we need to fire people, we need to retrench people. We need to turn them into temporary. They have to survive on their own, they have to think of the reality of life and for the organization. So I would say, at the point, I mean [a] few months before I left, the financial sustainability was a bit wobbly compared to right now. Because we want to take care of everyone, but the thing is we are taking care of everyone at the expense of ourselves. That was not sustainable. (Former Employee)

To cope with the financial pressure associated with care for others, Sky took on client projects that were one-off initiatives for publicity purposes, i.e., greenwashing projects, often related to major events, such as Earth Day. Such one-off projects had limited ecological impact in the long term and were not aligned with Sky's ecological mission which required continuous and dedicated effort. Yet, these projects enabled income generation to meet the financial pressures temporarily. Critically, these "greenwashing" projects, as they were described by members, were not taken on with a focus on achieving commercial goals because they aligned with the market logic, but to meet the norm of the family logic and support each other:

Of course, you will feel very responsible when you have staff on payroll, especially if they are looking after their parents or they have family or whatever. So that's... you don't want to think about... failing those kinds of people, but [...] you have to save the company, else you delay it. So those were definitely times when we made some bad decisions and took on some projects that in hindsight we would not have liked to take but... you feel at the moment that you have no choice and you have [to] do anything to kind of...keep...keep things turning over (Founder \#3)

The decision to downsize the organization and lay off members of Sky was eventually made in the face of bankruptcy, which would jeopardize both the market and ecological goals of the organization:

But because of the financial situation and all that we had to let go of half of them [...] So then we thought if we continue doing that, we are going to go bankrupt by...we did a calculation, by 6 or 8 months. So we thought we need to keep the company going, so we need to take this drastic measure to let go of them. It was a very, very painful thing to do. We've never let go of anyone... (Founder \#2) 
While the market and ecological logics influenced the decision to downsize, the family logic was enacted in two different ways when implementing the decision. First, the family logic was evident in members' commitment to the longevity of the organization. During the period of redundancies, members of the organization volunteered to be made redundant to ensure the longevity of the organization and its ecological mission. As Founder \#1 summarized the attitudes at the time and what members of the organization told them:

"We're okay to leave, as long as the company stays." In fact, they made me promise them that. (chuckles) "If I go, cool. You make sure that everything is sorted out." I was like, "Okay, we shake on that."

Second, the family logic was also enacted in how redundancy decisions were implemented. Some individuals were made redundant because their roles no longer existed after a restructuring to meet commercial and ecological goals. Care for them was demonstrated in multiple ways: providing flexibility in the notice period and additional support for those laid off, as explained by the financial manager:

We always look at your background if you could support yourselves or not without us. If not, we would give you a plan before you go, like a freelance window for two months until you find a job $[\ldots]$ he has a wife, the wife is not working, he has a son, a young son. If you let him go, immediately let him go, it's a bit harsh, because that person has no support from his parents, or he is supporting his parents. So those with the kind of background where one man is holding the family, and you want to let that man go immediately, a bit hard. Give him some time, like a few months, explain to him what's going on, see how he could fit in again, or see how we could provide for him first (Employee \#2)
Thus, beyond generating resources for shared demands with the market and ecological logics, the family logic also introduced new demands that conflicted with the demands prescribed by the other two logics.

\section{Discussion}

Our analysis shows that the family logic, characterized by shared particularized values, belonging, affective attachment, and norms of care, can emerge in non-kin social enterprises. This can happen in response to the challenges that social enterprises face due to their hybridity. As social enterprises combine market and ecological (or other non-market) logics, they lack legitimacy and the adequate resources, while also facing conflicting demands. In this context, the family logic can emerge and interact with the existing logics in fluid and multidimensional ways. The emergent family logic generates new resources to meet demands imposed by the market and ecological (or other non-market) logics in synergetic ways, while also introducing new conflicting demands and thus creating new tensions between embedded logics. As the organization navigates the tensions and makes use of the new resources generated by the family logic, the family logic becomes embedded within the organization over time (see Fig. 2). Our findings have implications for research in social entrepreneurship and family-owned firms in three distinct ways related to institutional logics within firms and to ethics of care.

First, we uncover the emergence of the family logic in a non-family-owned organization and thus offer the family logic as a new analytical lens through which to view social enterprises. While family-owned firms and social enterprises have been conceptually compared (e.g., Bacq \& Lumpkin, 2014; Börje \& Nordqvist, 2020; Whetten et al., 2014), the family logic itself has been neglected in the social
Fig. 2 Embedding the family logic in a social enterprise

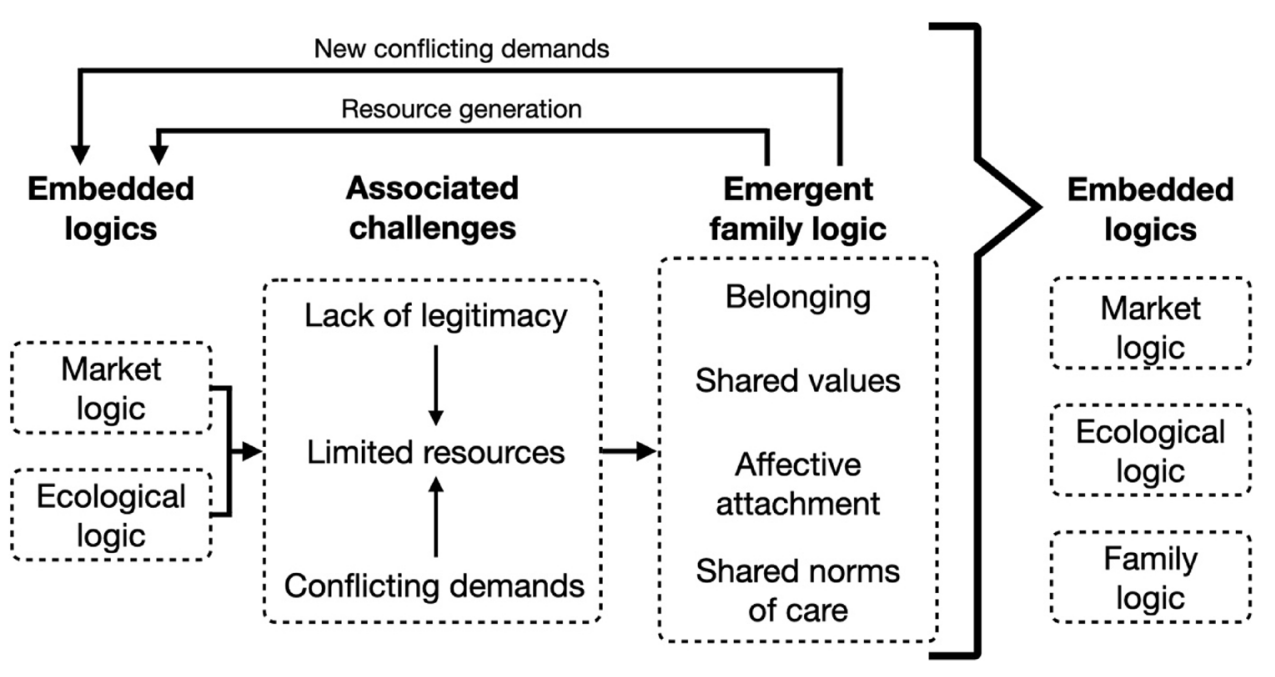


entrepreneurship literature, yet is important for understanding the experiences of internal stakeholders and actions and norms within some social enterprises. Interestingly, in our investigation the family logic emerged in an organization without kinship ties. By surfacing the family logic, behaviors and decisions that seem illogical or undesirable within social enterprises can be better understood. For example, delays in downsizing the organization, taking on work not aligned with the mission of the organization to protect jobs, providing additional income-generating opportunities to members of the organization and their families even when professional standards are not met seem less logical through the perspective of the ecological, social welfare or market logic. However, these behaviors and decisions are meaningful and logical when seen through the family logic lens (De Massis et al., 2008; Gomez-Mejia et al., 2011) whereby the family ties and the family unit are protected potentially at the expense of the financial sustainability of the organization or its mission. Additionally, the family logic emphasizes internal stakeholders (i.e., employees), which complements the current focus on external stakeholders, such as beneficiaries (as per the social welfare logic) and customers (as per the market logic) (e.g., Muñoz et al., 2018).

Indeed, it is possible for the family logic to be present in social enterprises in multiple ways, beyond spontaneous emergence as in Sky. On the one hand, the family logic can be embedded in social enterprises due to the social issues they aim to address. For example, social issues related to families where the family logic can play a role in how the social issue is conceptualized to define the entrepreneurial opportunity, how products and services are developed and delivered, or how the social enterprise communicates with beneficiaries in paternalistic ways (Skelcher \& Smith, 2015). On the other hand, the family logic can be present in familyowned social enterprises with implications for ownership and governance structures (Börje \& Nordqvist, 2020; Brundin et al., 2014) due to kinship ties within the organization. Overall, future research is required to examine the different ways the family logic can be embedded in some social enterprises by design or through emergence. Additionally, future research is needed to investigate the impact of the family logic in social enterprises not only for the organization but also for its diverse stakeholders, including employees and beneficiaries.

Second, empirically examining the family institutional logic in a non-kin social enterprise along with the ecological and market logics also offers initial insights into the interactions between these three logics beyond constant conflict with relevance to social entrepreneurship and family-ownered business research. The extant research in social entrepreneurship has predominantly focused on two contradictory logics (c.f., Mongelli et al., 2019), usually presented as posing incompatible goals, activities, and norms that are static and continuously shaping competing demands in the same way over time. Yet, emerging research, particularly in cross-sectoral partnership with social enterprises (e.g., Gottlieb et al., 2020; Jay, 2013; Savarese et al., 2020), demonstrates that duality is not the only form of hybrid organizing among social enterprises. Our findings contribute to this stream of research and explicate how the family, market, and ecological logics can interact in fluid and dynamic ways, beyond just permanent contradiction.

Our case study unearths how the challenges and tensions of combining the market and ecological logics provides a foundation for the family logic to emerge as a 'coping mechanism' that allows the organization to navigate the tensions, at least to a degree. Consequently, our findings surface contradiction between the family, ecological, and market logics based on the mechanisms of introducing new demands, and synergy based on generating new resources for shared goals. In line with the extant literature (e.g., Battilana \& Dorado, 2010; Pache \& Santos, 2013), our analysis shows how the family logic introduces new demands in the organization that can contradict those representing the market and ecological logics. For example, damaging professionalism and financial sustainability, which are prescribed by the market logic, or taking on greenwashing projects, which counter the ecological logic, to protect and support "the family". The research on family-owned firms also suggests that the family logic can contradict the market and ecological logics because it can limit innovation due to limited external perspectives and groupthink (Arregle et al., 2007).

However, the enactment of the family logic can also generate new resources to act in synergetic ways with the market and ecological logics when there are shared goals, thus serving the other two logics. In our study, the family and the ecological logics overlapped because the family logic was developed based on shared ecological values and a sense of belonging to a community with such values. The family logic was also synergetic with the market logic because it enabled the organization to meet its commercial needs with limited resources as employees tolerated lower pay and engaged in extra-role activities beyond their formal job descriptions to ensure unity and continuity of the values of the organization. Indeed, in relation to firm survival, all three logics converged and shared the goal of continuity, which from the family logic perspective included individuals volunteering for redundancies to ensure that the organization and its values continued. Such multidirectional and fluid interactions between the family, market, and ecological logics are relevant not only for ecological social enterprises, but also for family-owned firms which are known to exhibit high levels of corporate social responsibility and community citizenship (e.g., Berrone et al., 2010; de la Cruz Déniz Déniz and Suárez, 2005; Dyer \& Whetten, 2006) and thus may embed the ecological logic. 
Moving beyond duality to explore how multiple logics interact in different ways in social enterprises is important because it acknowledges that different interactions may influence organizational practices and individuals' lived experiences in various ways, while also enhancing our understanding of the heterogeneity of social enterprises. While in our case the family logic emerged, other logics may also exist within social enterprises, beyond the market and social welfare or ecological, that deserve attention. For example, social enterprises may enact specific professional logics associated with the social issue or the solution, such as a healthcare logic in social enterprises that address health-related issues, or a religious logic in social enterprises that emerge as projects started by churches or charity-based micro-finance organizations that embed Islamic economics. Thus, future research can benefit from first explicating which logics are enacted within the social enterprises under investigation and then exploring their relationships and outcomes, instead of assuming only two conflicting logics. Indeed, a concerted focus on so far neglected logics, such as specific professional logics, can be valuable for understanding the heterogeneity of social enterprises and uncovering distinct facets and dynamics of organizations that are currently experienced in isolation, such as issues related to career progression, gender equity, change initiatives, or work-life balance (e.g., Malhotra et al., 2020).

Third, our findings offer novel insights for social enterprises and family-owned firms from the perspective of ethics of care and the tough ethical balance for these organizations. At the core of our analysis in how the family logic is enacted is the norm of care and caring relationships among members of the organization. The norm of care and caring relationships is aligned with ethics of care driven by responsibility for enhancing and supporting the wellbeing of others and sensitivity to the interpersonal consequences of one's actions (Thompson, 1996). Ethics of care are relational, emphasizing mutual respect (Tronto, 1993) and maintaining connections among people (Gilligan, 1982) whereby interpersonal and situational factors should be considered, not just principles of justice and fairness applied blindly across all situations and individuals. In our analysis, caring relationships and norms were established as a part of the family logic and enacted through organizational citizenship behaviors (OCBs; Organ, 1997), organizational practices, and budgets. Our findings raise questions about the ethical responsibilities of social enterprises not only toward beneficiaries concerning benefit, mission drift, voice, and governance (Bull \& Ridley-Duff, 2019; Ramus \& Vaccaro, 2017), which has been the focus so far, but also toward (potential) employees, with relevance to family-owned firms.

The emergence of aspects related to ethics of care in our case study is not surprising, when viewed retrospectively. Ethics of care have been considered in the context of both social enterprises (e.g., André \& Pache, 2016; Magrizos \& Roumpi, 2020) and family-owned firms (e.g., Long \& Mathews, 2011). Meanwhile, ethics of care can be related to the family and ecological logics. The principles of ethics of care and its early emergence as an analytical concept in studies of relational responsibilities in the domestic sphere, where its principles and practice are most easily visible (Folbre, 2012; Held, 2006), aligns with the notion of the family as an institution that prioritizes connection and care. Ethics of care are also evident in ecological and climate action movements where the ecological logic is most clearly articulated. Ecological and climate action movements emphasize the role of caring for all kinds of others, not just humans, and the complex connections and interdependencies within and between ecological systems. Ecological and climate action movements also often cite the lack of care as a fundamental driver of the climate crisis (Beacham, 2018; Nicholson \& Kurucz, 2019; Whyte \& Cuomo, 2017). Care, compassion, and relational concerns as the bases for action and decision making are thus ontologically different from the emphasis in the market logic on fairness and justice based on rigid rules and impersonal decision making that applies across situations, which better aligns with principle and justice theories of ethics. Thus, the different ontological positions of ethical frameworks aligned with different institutional logics are another site for tensions and contradictions between institutional logics within organizations.

Ethics of care can arguably maintain the mission of social enterprises (André \& Pache, 2016) and in many ways can benefit the wellbeing of employees through providing them with the support they need. Yet, ethics of care can also introduce new ethical challenges in practice for organizations in relation to those inside and outside of the organization. Inside the organization, caring norms and relationships, demonstrated through OCBs in addition to one's formal responsibilities, can put normative pressure on individuals. While informal, employees may feel obliged to engage in OCBs, yet not all employees have the resources to engage in OCBs, for example, due to caring responsibilities outside of the organization or health issues. Such unequal opportunities and resources to engage in OCBs and to give care to others can lead to issues related to stress and burnout (Bolino et al., 2010) and exclude those with limited resources and capacity to provide care. Outside the organization, caring norms and relationships can exclude outsiders. Ethics of care are relational and, as demonstrated in the family ownership literature (e.g., Bingham et al., 2011; Chrisman et al., 2014; Chua et al., 2009) and in our findings, caring norms and relationships prioritize those inside the organization or inside the family with whom relationships are already established and situational factors are known. However, this can exclude outsiders who may also need care. Indeed, in line with ethics of care, such situational and relational aspects for employees 
and outsiders alike would be considered. Yet, in practice, enacting ethics of care inside organizations is challenging because there is a need to recognize how caring norms and relationships may also be harmful.

\section{Limitations}

With this inductive case study, we explored how the enactment of the family logic in an ecological social enterprise interacts with the ecological and market logics. Like all research, this study has several limitations which we acknowledge to propose a series of avenues for future research. First, this is an inductive study based on a single case that offers the potential for rich theoretical insights. While we relied on multiple sources of data to triangulate accounts and employed several methods to ensure the trustworthiness of our findings, future research is needed to explore the transferability of our findings across organizational and institutional settings. This includes further explicating and testing our findings with diverse social enterprises in terms of their mission, size, and location in a single site or across multiple sites because these factors may play a role in whether the family logic emerges or how it is enacted.

Second, our study took place in Malaysia, which may have influenced our findings and their transferability. While we see our country context as a strength due to the limited research on social entrepreneurship in Malaysia (c.f., $\mathrm{Au}$ et al., 2021), it is also possible that the limited understanding of ecological practices and values in the country may have influenced our findings in enhancing the need for those who adopt ecological practices to seek individuals with shared values and to pursue belonging to a community with these values, which contributed to the emergence of the family logic in our case. However, in institutional contexts where ecological values and practices are more common, the need for belonging based on shared ecological values may be limited, thus influencing whether a family logic emerges in the first place. Thus, research with social enterprises based in institutional settings where ecological values are common is needed to extend the transferability of the findings.

\section{Conclusion}

We extend social entrepreneurship research by explicating how the family institutional logic is enacted within an ecological social enterprise without kinship ties in ways that create synergies and new tensions with the ecological and market logics. By drawing attention to a neglected institutional logic in the social entrepreneurship domain, our findings have implications for family-owned firms and social enterprises in relation to ethics of care and interactions between logics.
Acknowledgements We thank Editor Julia Roloff and the reviewers for their constructive comments and guidance. An earlier version of this article was presented at the International Social Innovation Research Conference 2020 in Sheffield, UK. We thank the participants for their helpful feedback.

Funding This study was funded by Grant AH/R005354/1.

\section{Declarations}

Conflict of interest All authors declare no conflicts of interest.

Ethical Approval All procedures performed in the study involving human participants were in accordance with the ethical standards of the institutional research committee and with the 1964 Helsinki declaration and its later amendments.

Informed Consent Informed consent was obtained from all individual participants included in the study.

Open Access This article is licensed under a Creative Commons Attribution 4.0 International License, which permits use, sharing, adaptation, distribution and reproduction in any medium or format, as long as you give appropriate credit to the original author(s) and the source, provide a link to the Creative Commons licence, and indicate if changes were made. The images or other third party material in this article are included in the article's Creative Commons licence, unless indicated otherwise in a credit line to the material. If material is not included in the article's Creative Commons licence and your intended use is not permitted by statutory regulation or exceeds the permitted use, you will need to obtain permission directly from the copyright holder. To view a copy of this licence, visit http://creativecommons.org/licenses/by/4.0/.

\section{References}

Au, W. C., Drencheva, A., \& Yew, J. L. (2021). Narrating career in social entrepreneurship: Experiences of social entrepreneurs. Journal of Social Entrepreneurship. https://doi.org/10.1080/19420 676.2021.1890188

André, K., \& Pache, A.-C. (2016). From caring entrepreneur to caring enterprise: Addressing the ethical challenges of scaling up social enterprises. Journal of Business Ethics, 133(4), 659-675.

Arregle, J.-L., Hitt, M. A., Sirmon, D. G., \& Very, P. (2007). The development of organizational social capital: Attributes of family firms. Journal of Management Studies, 44(1), 73-95.

Bacq, S., \& Lumpkin, G. T. (2014). Can social entrepreneurship researchers learn from family business scholarship? A theorybased future research agenda. Journal of Social Entrepreneurship, 5(3), 270-294.

Battilana, J., \& Dorado, S. (2010). Building sustainable hybrid organizations: The case of commercial microfinance organizations. Academy of Management Journal, 53, 1419-1440.

Battilana, J., Sengul, M., Pache, A. C., \& Model, J. (2015). Harnessing productive tensions in hybrid organizations: The case of work integration social enterprises. Academy of Management Journal, $58,1658-1685$.

Beacham, J. (2018). Organising food differently: Towards a more-thanhuman ethics of care for the Anthropocene. Organization, 25(4), 533-549.

Berrone, P., Cruz, C., Gomez-Mejia, L. R., \& Larraza-Kintana, M. (2010). Socioemotional wealth and corporate responses to 
institutional pressures: Do family-controlled firms pollute less? Administrative Science Quarterly, 55(1), 82-113.

Besharov, M. L., \& Smith, W. K. (2014). Multiple institutional logics in organisations: Explaining their varied nature and implications. Academy of Management Review, 39, 364-381.

Bingham, J., Jr., W., Smith, I., \& Adams, G. (2011). A stakeholder identity orientation approach to corporate social performance in family firms. Journal of Business Ethics, 99, 565-585.

Boers, B., \& Nordqvist, M. (2012). Understanding hybrid-identity organizations: The case of publicly listed family businesses. In A. Carsrud \& M. Brännback (Eds.), understanding family businesses: Undiscovered approaches, unique perspectives, and neglected topics (pp. 251-269). Springer.

Bolino, M., Valcea, S., \& Harvey, J. (2010). Employee, manage thyself: The potentially negative implications of expecting employees to behave proactively. Journal of Occupational and Organizational Psychology, 83(2), 325-345.

Börje, B., \& Nordqvist, M. (2020). Family businesses as hybrid organisations. In D. Billis \& C. Rochester (Eds.), Handbook on hybrid organisations (pp. 507-521). Edward Elgar Publishing.

Brundin, E., Samuelsson, E. F., \& Melin, L. (2014). Family ownership logic: Framing the core characteristics of family businesses. Journal of Management and Organization, 20(1), 6-37.

Bull, M., \& Ridley-Duff, R. (2019). Towards an appreciation of ethics in social enterprise business models. Journal of Business Ethics, 159, 619-634.

Corley, K., \& Gioia, D. (2004). Identity ambiguity and change in the wake of a corporate spin-off. Administrative Science Quarterly, 49, 173-208.

Cruz, C., Justo, R., \& De Castro, J. O. (2012). Does family employment enhance MSEs performance? Journal of Business Venturing, 27, 62-76.

Chrisman, J. J., Chua, J. H., \& Litz, R. (2003). A unified systems perspective of family firm performance: An extension and integration. Journal of Business Venturing, 18(4), 467-472.

Chrisman, J. J., Chua, J. H., \& Steier, L. (2005). Sources and consequences of distinctive familiness: An introduction. Entrepreneurship Theory and Practice, 29(3), 237-247.

Chrisman, J. J., Memili, E., \& Misra, K. (2014). Nonfamily managers, family firms, and the winner's curse: The influence of noneconomic goals and bounded rationality. Entrepreneurship Theory and Practice, 38(5), 1-25.

Davis, M. S. (1971). That's interesting: Towards a phenomenology of sociology and a sociology of phenomenology. Philosophy of the Social Sciences, 1, 309-344.

de la Cruz Déniz Déniz, M., \& Suárez, M. K. C. (2005). Corporate social responsibility and family business in Spain. Journal of Business Ethics, 56(1), 27-41.

De Massis, A., Chua, J. H., \& Chrisman, J. J. (2008). Factors preventing intra-family succession. Family Business Review, 21, 183-199.

DiMaggio, P. J., \& Powell, W. W. (1983). The iron cage revisited: Institutional isomorphism and collective rationality in organizational fields. American Sociological Review, 48, 147-160.

Doherty, B., Haugh, H., \& Lyon, F. (2014). Social enterprises as hybrid organizations: A review and research agenda. International Journal of Management Reviews, 16, 417-436.

Dyer, W. G. (2003). The family: The missing variable in oganizational research. Entrepreneurship Theory and Practice, 27, 401-416.

Dyer, W. G., \& Whetten, D. A. (2006). Family firms and social responsibility: Preliminary evidence from the SandP 500. Entrepreneurship Theory and Practice, 30, 785-802.

Edmondson, A., \& McManus, S. (2007). Methodological fit in management field research. Academy of Management Review, 32, $1155-1179$.
Eisenhardt, K. M. (1989). Building theories from case study research. Academy of Management Review, 14, 532-550.

Fathallah, R., Sidani, Y., \& Khalil, S. (2020). How religion shapes family business ethical behaviors: An institutional logics perspective. Journal of Business Ethics, 163(4), 647-659.

Fisher, G., Kuratko, D. F., Bloodgood, J. M., \& Hornsby, J. S. (2017). Legitimate to whom? The challenge of audience diversity and new venture legitimacy. Journal of Business Venturing, 32, 52-71.

Folbre, N. (2012). For the love of money: Care provision in the United States. Russell Sage Foundation.

Friedland, R., \& Alford, R. (1991). Bringing society back in. In W. W. Powell \& P. J. DiMaggio (Eds.), The new institutionalism in organizational analysis (pp. 232-266). University of Chicago Press.

Galaskiewicz, J., \& Barringer, S. N. (2012). Social enterprises and social categories. In B. Gidron \& Y. Hasenfeld (Eds.), Social enterprises: An organizational perspective (pp. 47-70). Palgrave Macmillan.

Gilligan, C. (1982). In a different voice: Psychological theory and women's development. Harvard University Press.

Gioia, D. A., Corley, K. G., \& Hamilton, A. L. (2013). Seeking qualitative rigor in inductive research: Notes on the Gioia methodology. Organizational Research Methods, 16, 15-31.

Gomez-Mejia, L. R., Cruz, C., Berrone, P., \& Castro, J. (2011). The bind that ties: Socioemotional wealth preservation in family firms. Academy of Management Annals, 5, 653-707.

Gomez-Mejia, L. R., Haynes, K. T., Núñez-Nickel, M., Jacobson, K. J. L., \& Moyano-Fuentes, J. (2007). Socioemotional wealth and business risks in family-controlled firms: Evidence from Spanish olive oil mills. Administrative Science Quarterly, 52, 106-137.

Gottlieb, S. C., Frederiksen, N., Koch, C., \& Thuesen, C. (2020). Hybrid organisations as trading zones: Responses to institutional complexity in the shaping of strategic partnerships. Construction Management and Economics, 38, 603-622.

Greenwood, R., Díaz, A. M., Li, S. X., \& Lorente, J. C. (2010). The multiplicity of institutional logics and the heterogeneity of organizational responses. Organization Science, 21, 521-539.

Greenwood, R., Raynard, M., Kodeih, F., Micelotta, E. R., \& Lounsbury, M. (2011). Institutional complexity and organizational responses. Academy of Management Annals, 5, 317-371.

Habbershon, T. G., \& Pistrui, J. (2002). Enterprising families domain: Family-influenced ownership groups in pursuit of transgenerational wealth. Family Business Review, 15, 223-237.

Habbershon, T. G., Williams, M., \& MacMillan, I. C. (2003). A unified systems perspective of family firm performance. Journal of Business Venturing, 18(4), 451-465.

Held, V. (2006). The ethics of care: Personal, political, and global. Oxford University Press.

Henry, C., \& Foss, L. (2015). Case sensitive? A review of the literature on the use of case method in entrepreneurship research. International Journal of Entrepreneurial Behavior and Research, 21, 389-409.

Hoffman, J., Hoelscher, M., \& Sorenson, R. (2016). Achieving sustained competitive advantage: A family capital theory. Family Business Review, 19(2), 135-145.

Jaskiewicz, P., Heinrichs, K., Rau, S. B., \& Reay, T. (2016). To be or not to be: How family firms manage family and commercial logics in succession. Entrepreneurship Theory and Practice, 40, 781-813.

Jay, J. (2013). Navigating paradox as a mechanisim of change and innovation in hybrid organizations. Academy of Management Journal, $56,137-159$.

Kalm, M., \& Gomez-Mejia, L. R. (2016). Socioemotional wealth preservation in family firms. Revista De Administração, 51, 409-411. 
Laasch, O. (2018). Beyond the purely commercial business model: Organizational value logics and the heterogeneity of sustainability business models. Long Range Planning, 51(1), 158-183.

Langley, A., \& Abdallah, C. (2011). Templates and turns in qualitative studies of strategy and management. Research Methodology in Strategy and Management, 6, 201-235.

Lincoln, Y. S. and Guba, E. G. (1985). Naturalistic Inquiry. Sage.

Long, R. G., \& Mathews, K. M. (2011). Ethics in the family firm: Cohesion through reciprocity and exchange. Business Ethics Quarterly, 21(2), 287-308.

Lubatkin, M. H., Schulze, W. S., Ling, Y., \& Dino, R. N. (2005). The effects of parental altruism on the governance of family-managed firms. Journal of Organizational Behavior, 26(3), 313-330.

MaGIC - Malaysian Global Innovation \& Creativity Centre. (2019). Social enterprise accreditation. MaGIC. Retrieved November 01, 2021, from https://central.mymagic.my/sea.

Magrizos, S., \& Roumpi, D. (2020). Doing the right thing or doing things right? The role of ethics of care and ethics of justice in human resource management of social enterprises. Strategic Change, 29(4), 485-496.

Mair, J., Battilana, J., \& Cardenas, J. (2012). Organizing for society: A typology of social entrepreneuring models. Journal of Business Ethics, 111, 353-373.

Mair, J., Mayer, J., \& Lutz, E. (2015). Navigating institutional plurality: Organizational governance in hybrid organizations. Organization Studies, 36, 713-739.

Malhotra, N., Zietsma, C., Morris, T., \& Smets, M. (2020). Handling resistance to change when societal and workplace logics conflict. Administrative Science Quarterly. https://doi.org/10.1177/00018 39220962760

Miller, D., Breton-Miller, I. L., \& Lester, R. H. (2011). Family and lone founder ownership and strategic behaviour: Social context, identity, and institutional logics. Journal of Management Studies, $48,1-25$.

Miller, D., \& Le Breton-Miller, I. (2005). Management insights from great and struggling family businesses. Long Range Planning, $38(6), 517-530$

Mongelli, L., Rullani, F., Ramus, T., \& Rimac, T. (2019). The bright side of hybridity: Exploring how social enterprises manage and leverage their hybrid nature. Journal of Business Ethics, 159, 301-305

Muñoz, P., Cacciotti, G., \& Cohen, B. (2018). The Double-edged sword of purpose-driven behavior in sustainable venturing. Journal of Business Venturing, 33, 149-178.

Nicholson, J., \& Kurucz, E. (2019). Relational leadership for sustainability: Building an ethical framework from the moral theory of 'ethics of care.' Journal of Business Ethics, 156(1), 25-43.

Ocasio, W., \& Radoynovska, N. (2016). Strategy and commitments to institutional logics: Organizational heterogeneity in business models and governance. Strategic Organization, 14, 287-309.

Organ, D. W. (1997). Organizational citizenship behavior: It's construct clean-up time. Human Performance, 10(2), 85-97.

Pache, A. C., \& Santos, F. (2013). Inside the hybrid organization: Selective coupling as a response to competing institutional logics. Academy of Management Journal, 56, 972-1001.

Ramus, T., \& Vaccaro, A. (2017). Stakeholders matter: How social enterprises address mission drift. Journal of Business Ethics, 143, 307-322.

Reay, T., \& Hinings, C. R. (2009). Managing the rivalry of competing institutional logics. Organization Studies, 30, 629-652.

Rowley, T., Behrens, D., \& Krackhardt, D. (2000). Redundant governance structures: An analysis of structural and relational embeddedness in the steel and semiconductor industries. Strategic Management Journal, 21, 369-386.

Savarese, C., Huybrechts, B., \& Hudon, M. (2020). The influence of interorganizational collaboration on logic conciliation and tensions within hybrid organizations: Insights from social enterprise-corporate collaborations. Journal of Business Ethics. https://doi.org/10.1007/s10551-020-04557-7

Schulze, W. S., Lubatkin, M. H., \& Dino, R. N. (2003). Exploring the agency consequences of ownership dispersion among the directors of private family firms. Academy of Management Journal, 46, 179-194.

Schulze, W. S., Lubatkin, M. H., Dino, R. N., \& Buchholtz, A. K. (2001). Agency relationships in family firms: Theory and evidence. Organization Science, 12, 99-116.

Short, J. C., Moss, T. W., \& Lumpkin, G. T. (2009). Research in social entrepreneurship: Past contributions and future opportunities. Strategic Entrepreneurship Journal, 3(2), 161-194.

Skelcher, C., \& Smith, S. R. (2015). Theorizing hybridity: Institutional logics, complex organizations, and actor identities: The case of nonprofits. Public Administration, 93, 433-448.

Sorenson, R. L. (2000). The contribution of leadership style and practices to family and business success. Family Business Review, 13, 183-200.

Suchman, M. C. (1995). Managing legitimacy: Strategic and institutional approaches. Academy of Management Review, 20(3), 571-610.

Stephan, U., \& Drencheva, A. (2017). The person in social entrepreneurship: A systematic review of research on the social entrepreneurial personality. In G. Ahmetoglu, T. Chamorro-Premuzic, B. Klinger, \& T. Karcisky (Eds.), The Wiley Handbook of Entrepreneurship (pp. 205-230). John Wiley.

Thompson, C. J. (1996). Caring consumers: Gendered consumption meanings and the juggling lifestyle. Journal of Consumer Research, 22(4), 388-407.

Thornton, P. H., Ocasio, W., \& Lounsbury, M. (2012). The institutional logics perspective: A new approach to culture. Oxford University Press.

Tracey, P., Phillips, N., \& Jarvis, O. (2011). Bridging institutional entrepreneurship and the creation of new organizational forms: A multilevel model. Organization Science, 22, 60-80.

Tronto, J. (1993). Moral boundaries: A political argument for an ethic of care. Routledge.

Vaskelainen, T., \& Münzel, K. (2018). The effect of institutional logics on business model development in the sharing economy: The case of German carsharing services. Academy of Management Discoveries, 4, 273-293.

Whetten, D., Foreman, P., \& Dyer, W. G. (2014). Organizational identity and family business. In M. Nordqvist, L. Melin, \& P. Sharma (Eds.), The SAGE handbook of family business (pp. 480-497). SAGE.

Whyte, K. P., \& Cuomo, C. J. (2017). Ethics of caring in environmental ethics. In S. M. Gardiner \& A. Thompson (Eds.), The Oxford Handbook of environmental ethics (pp. 234-247). Oxford University Press.

Yin, R. K. (2003). Case study research: Design and methods. SAGE.

York, J. G., O’Neil, I., \& Sarasvathy, S. D. (2016). Exploring environmental entrepreneurship: Identity coupling, venture goals, and stakeholder incentives. Journal of Management Studies, 53, 695-737.

Zietsma, C., \& Lawrence, T. B. (2010). Institutional work in the transformation of an organizational field: The interplay of boundary work and practice work. Administrative Science Quarterly, 55, 189-221.

Zilber, T. B. (2002). Institutionalization as an interplay between actions, meanings, and actors: The case of a rape crisis center in Israel. Academy of Management Journal, 45, 234-254.

Publisher's Note Springer Nature remains neutral with regard to jurisdictional claims in published maps and institutional affiliations. 